\title{
Halal Tourism Management And Development Strategy Based on Qanun Number 8 The Year 2013
}

\author{
$1^{\text {st }}$ Sugiharto ${ }^{1}, 2^{\text {nd }}$ Darwin Parlaungan Lubis ${ }^{2}, 3^{\text {rd }}$ Mbina Pinem $^{3}, 4^{\text {th }}$ Ease Arent $^{4}, 5^{\text {th }}$ Cut Fadhira $^{5}$ \\ \{ sugihgeo.unimed@gmail.com ${ }^{1}$, darwinparlaunganlubis@gmail.com ${ }^{2}$, mbinapinem@gmail.com ${ }^{3}$, \\ easearent1@gmail.com ${ }^{4}$, cutfadhira09@gmail.com $\left.{ }^{5}\right\}$
}

J1. Willem Iskandar Pasar V Medan Estate, Medan, Sumatera Utara, 20221, Indonesia ${ }^{1,2,3,4,5}$.

\begin{abstract}
The sector that can increase employment and current economic growth is tourism. The city of Sabang is one of the tourist destinations that present natural and social beauty. In the development of the town of Sabang in the province of Aceh, which is known as the Veranda of Mecca. As the Veranda of Mecca in Aceh, in managing the tourism development of Sabang, it applies the concept of halal tourism. High tourist interest in halal tourism is in line with the increase in Middle Eastern tourists to Kota Sabang. This study focuses on the management and development strategy of halal tourism in Kota Sabang. The method used to determine the development strategy is a SWOT analysis by analyzing the opportunities and threats using the EFAS analysis matrix. The research locations were in 25 tourist destinations with 130 tourists and 30 business people, 50 local people, and five from the tourism office. The results showed that the total weighted value of the EFAS matrix had an opportunity and threat value of 2.187 and 0.54 . The data shows that the position on the SWOT diagram is in Quadrant I, which means it has possibilities and strengths
\end{abstract}

Keywords: Halal Tourism, SWOT Analysis, Sabang, Aceh

\section{Introduction}

The development of tourism has attracted worldwide attention. The tourism sector has developed into an industrial sector that provides benefits to local communities and tourists. Tourism development is generally influenced by the facilities and infrastructure found in the destination [1]; [2]; [3]. Adequate facilities and infrastructure affect income to the state and society.

The development of halal tourism has given attention to tourists. Halal tourism is growing rapidly, and tourists' increasing knowledge and awareness about halal products [4]; [5]. Halal tourism is often also defined as tourism representing activities allowed according to Islamic teachings in terms of behavior, clothing, and food [6]; [7]. Halal tourism is also related to the provision of tourism products and services that meet the needs of Muslim tourists and the availability of tourism products and services [8]; [9]. As an effort to develop halal tourism, Indonesia has made efforts to increase the presence of sharia hotels. The government has also made guidelines for the implementation of sharia hotels. The Sharia hotel in question is regulated by the MUI Fatwa [7].

One of the provinces that implement the Islamic sharia system is Aceh. Therefore, the province of Aceh is known as the Veranda of Mecca [10]; [11]. The province of Aceh has an important role in the spread of Islam in Indonesia and Southeast Asia. Aceh province also has tourism potential, both natural, artificial, and religious tourism [12]; [13]. The recognition of 
Aceh as the Veranda of Mecca and having natural, artificial, and religious tourist destinations are the main supporters in the development of halal tourism in Aceh Province [14] [15].

Weh Island is one of the islands in Aceh Province. Weh Island has fairly high tourism potential, especially coastal tourism. Besides having marine tourism, Pulau Weh also has historical sites that are a special attraction for tourists. The management of tourism development on Pulau Weh is regulated in regional regulations or Aceh Qanun No. 8 of 2013. An important point in carrying out tourism according to Aceh Qanun No. 8 of 2013 [16] Article 83, namely, 1) domestic and foreign tourists are required to dress modestly; 2) Muslim tourists are required to dress according to Islamic law; 3) There is a separation of baths between men and women; 4) Tourists who want to watch shows/entertainment have a separation between men and women; 5) Entrepreneurs, community groups or government apparatus and business entities are prohibited from providing facilitation facilities and protecting people from carrying out activities that violate Islamic Shari'a; 6) Everyone is obliged to prevent the occurrence of immoral acts. (ACEH QANUN NUMBER 8 THE YEAR 2013 CONCERNING TOURISM, 2013) This paper aims to analyze the management strategy of halal tourism in Pulau Weh using a SWOT analysis.

\section{Method}

The data analysis method used in this research is SWOT analysis with EFAS matrix. SWOT analysis is used to structure the problem, especially by analyzing the strategic environment, commonly referred to as the internal environment and the external environment (Rangkuti, 2001). In this internal and external environment, four elements are always owned and faced: internally having several strengths and weaknesses, and externally facing various opportunities (opportunities) and threats (threats). The condition of facilities and infrastructure was analyzed using a scoring technique with a scale of 1-3. A scale of 1 means bad, two means moderate, 3 means good. Data collection was carried out on 25 tourist destinations in the city of Sabang with 265 informants. The informants consisted of 130 tourists, 30 business people, 50 local people, and five people from the tourism office.

\section{Results and Discussion}

\subsection{Study City}

The city of Sabang (Figure 1) is the westernmost region in the Republic of Indonesia. Geographically, Kota Sabang is located at coordinates 05o 46' 28" - 05o 54' 28" North Latitude (LU) and $95^{\circ} 13^{\prime} 02^{\prime \prime}-95^{\circ} 22^{\prime} 36^{\prime \prime}$ East Longitude (BT). The city of Sabang is bordered to the north and east by the Malacca Strait, to the south by the Bengal Strait, and the west by the Indonesian Ocean (www.sabangkota.go.id).

The city of Sabang is a city that is rich in natural resources wherewith this wealth, the town of Sabang is one of the cities as a tourist destination. This makes the city of Sabang the most prima donna among other cities or regencies in Aceh Province. 


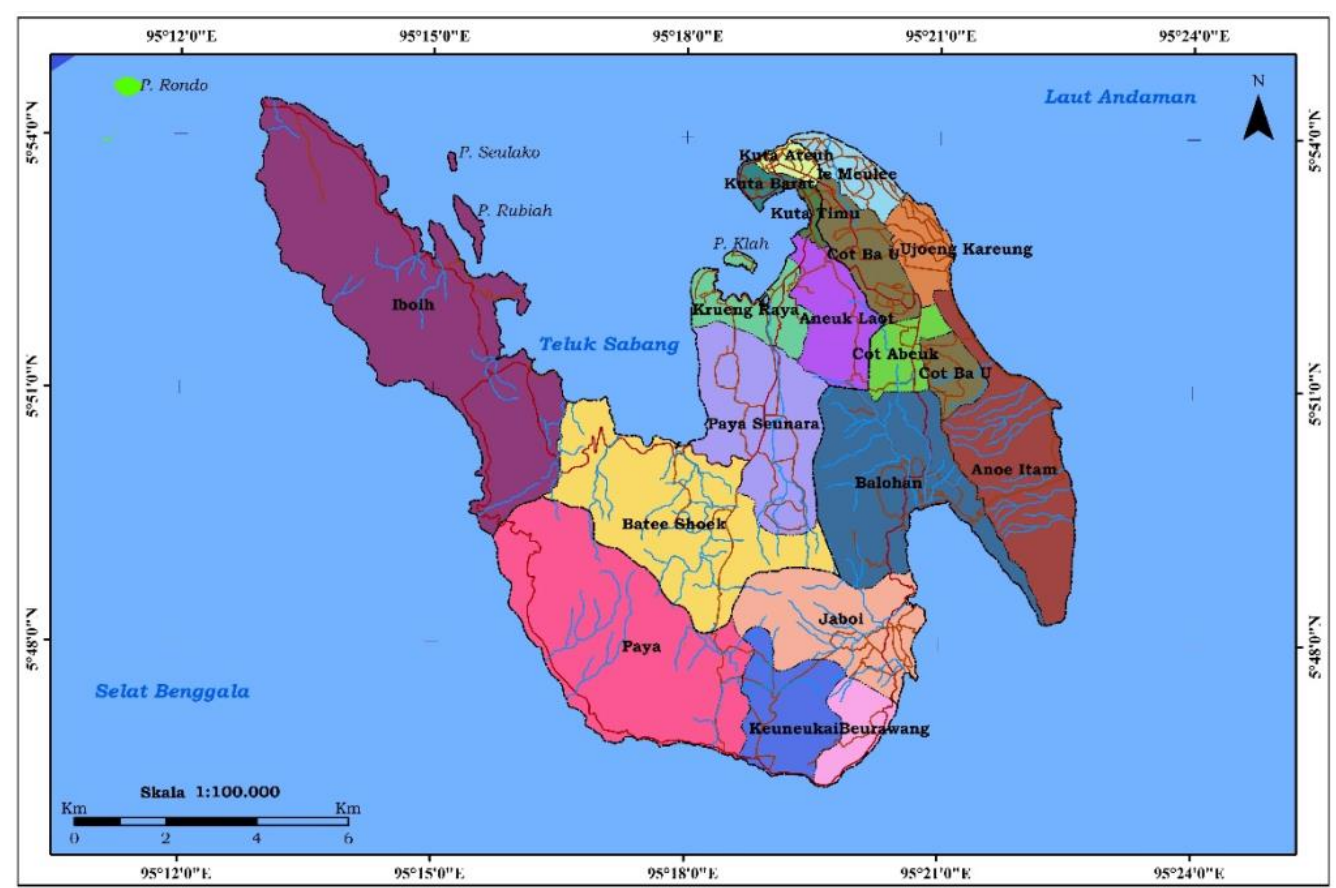

Fig 1. Research site administration map.

\subsection{Conditions of Kota Sabang Tourist Destinations}

The condition of a tourist destination is the condition of a tourism destination which is assessed based on the completeness of the elements of tourism implementation. In this study, the state of tourism destinations is evaluated based on the condition of the facilities and infrastructure available to support tourism activities. According to Ghani [17], tourism facilities are all forms of facilities to complement, support tourist destinations and aim to facilitate tourism activities so that they can run smoothly. Meanwhile, tourism infrastructure is all-natural resources and human resources that tourists need to support tourism activities such as roads, electricity, telecommunications, bridges, and so on (Suwantoro, 2004). For more details, the condition of the facilities and infrastructure of tourist destinations in Kota Sabang can be seen in Tables 1 and 2 below.

Table 1. Assessment of kota sabang tourist destination facilities.

\begin{tabular}{clccc}
\hline No. & \multicolumn{1}{c}{ Destinations } & $\begin{array}{c}\text { Amount } \\
\text { Score }\end{array}$ & Average & Information \\
\hline 1 & Danau Aneuk Laot & 8 & 1,142857143 & Bad \\
\hline 2 & PDAM Aneuk Laot & 8 & 1,142857143 & Bad \\
\hline 3 & Mercusuar Le Meulee & 11 & 1,571428571 & Bad \\
\hline 4 & Pantai Pasir Putih & 12 & 1,714285714 & Currently \\
\hline 5 & Benteng Jepang & 13 & 1,857142857 & Currently \\
\hline
\end{tabular}




\begin{tabular}{|c|c|c|c|c|}
\hline 6 & Tugu Kilometer nol sabang & 13 & 1,857142857 & Currently \\
\hline 7 & Gua Sarang & 14 & 2 & Currently \\
\hline 8 & Menera Merah Putih & 14 & 2 & Currently \\
\hline 9 & Pantai Iboh & 14 & 2 & Currently \\
\hline 10 & Pantai Jamboi & 14 & 2 & Currently \\
\hline 11 & Pantai Paradiso & 14 & 2 & Currently \\
\hline 12 & Point View Tugu Garuda & 14 & 2 & Currently \\
\hline 13 & Taman I love Sabang & 14 & 2 & Currently \\
\hline 14 & Tugu Garuda Iboh & 14 & 2 & Currently \\
\hline 15 & Dermaga Kota Sabang & 15 & 2,142857143 & Currently \\
\hline 16 & Pantai kasih & 15 & 2,142857143 & Currently \\
\hline 17 & Pantai Anoe Itam & 15 & 2,142857143 & Currently \\
\hline 18 & Pantai Tapak Gajah & 15 & 2,142857143 & Currently \\
\hline 19 & Pelabuhan Balohan & 15 & 2,142857143 & Currently \\
\hline 20 & Point View Benteng & 15 & 2,142857143 & Currently \\
\hline 21 & Pulau Rubiah & 15 & 2,142857143 & Currently \\
\hline 22 & Sabang Hill & 15 & 2,142857143 & Currently \\
\hline 23 & Tugu Cengkeh & 15 & 2,142857143 & Currently \\
\hline 24 & Mesjid Agung Sabang & 19 & 2,714285714 & Well \\
\hline 25 & Sumur Tiga & 20 & 2,857142857 & Well \\
\hline
\end{tabular}

Source: Research Data, 2021

Table 2. Assessment of kota sabang tourism destination infrastructure.

\begin{tabular}{llccc}
\hline No. & \multicolumn{1}{c}{ Destinations } & $\begin{array}{c}\text { Amount } \\
\text { Score }\end{array}$ & Average & Information \\
\hline 1 & Gua Sarang & 7 & 1,4 & Bad \\
\hline 2 & Danau Aneuk Laot & 8 & 1,6 & Bad \\
\hline 3 & Dermaga Kota Sabang & 8 & 1,6 & Bad \\
\hline 4 & Pantai Anoe Itam & 8 & 1,6 & Bad \\
\hline 5 & Pantai Iboh & 8 & 1,6 & Currently \\
\hline 6 & Pantai Jamboi & 9 & 1,8 & Currently \\
\hline 7 & Pantai Kasih & 10 & 2 & Currently \\
\hline 8 & Sumur Tiga & 10 & 2 & Currently \\
\hline 9 & Pantai Tapak Gajah & 10 & 2 & Currently \\
\hline 10 & Pulau Rubiah & 12 & 2,4 & Well \\
\hline
\end{tabular}




\begin{tabular}{clccc}
\hline 11 & Sabang Hill & 12 & 2,4 & Well \\
\hline 12 & Taman I Love Sabang & 12 & 2,4 & Well \\
\hline 13 & Tugu Kilometer Nol & 12 & 2,4 & Well \\
\hline 14 & Pantai Pasir Putih & 12 & 2,4 & Well \\
\hline 15 & PDAM Aneuk Laot & 12 & 2,4 & Well \\
\hline 16 & Mesjid Agung Sabang & 12 & 2,4 & Well \\
\hline 17 & Tugu Cengkeh & 12 & Well \\
\hline 18 & Point View Benteng & 12 & Well \\
\hline 19 & Point View Tugu Garuda & 12 & 2,4 & Well \\
\hline 20 & Mercusuar Le Meulee & 12 & 2,4 & Well \\
\hline 21 & Menera Merah Putiih & 12 & 2,4 & Well \\
\hline 22 & Pantai Paradiso & 12 & 2,4 & Well \\
\hline 23 & Pelabuhan Balohan & 12 & 2,4 & Well \\
\hline 24 & Benteng Jepang & 12 & 2,4 & Well
\end{tabular}

Based on table 1, the condition of facilities at 25 tourist destinations in Sabang, three tourist destinations are in the wrong category, 20 in the medium type and the rest in the good class. The assessment of tourist destination facilities is seen from several aspects, namely transportation, public toilets, parking lots, trash cans, restaurants/food stalls, souvenirs, and places of worship. While table 2 the condition of infrastructure at 25 tourist destinations in Sabang; there are four tourist destinations in the wrong category, 5 in the medium type, and the rest in the good class. The infrastructure condition assessment is seen from several aspects, namely the road network, electricity network, banking, health services, and clean water networks. Based on the recapitulation of existing facilities and infrastructure in Kota Sabang tourism destinations, it can be categorized as good. However, some facilities lack maintenance, such as public bathrooms that are poorly maintained and maintained. In addition, the lack of water in the bathrooms makes it difficult for tourists to urinate/large and take ablution water for prayer because there is no water.

\subsection{Understanding of Qanun Number 8 of 2013}

Qanun Number 13 of 2013 is a regional regulation issued by the Aceh Regional Government in 2013 which regulates tourism in Aceh. This regulation is expected to guide carrying out tourism activities by government regulations and Islamic law so that Aceh tourism has special features. Currently, many Acehnese still does not know about the local rules governing tourism. Based on the interviews with tourists who became respondents, $78 \%$ of tourists already knew about the regional regulation of Qanun No. 8 of 2013 but did not know the contents of the law, and 22\% did not know about Qanun No. 8 of 2013. For more details, the percentage of understanding about Qanun No. 8 of 20132013 [16] can be seen in Figure 2 below. 


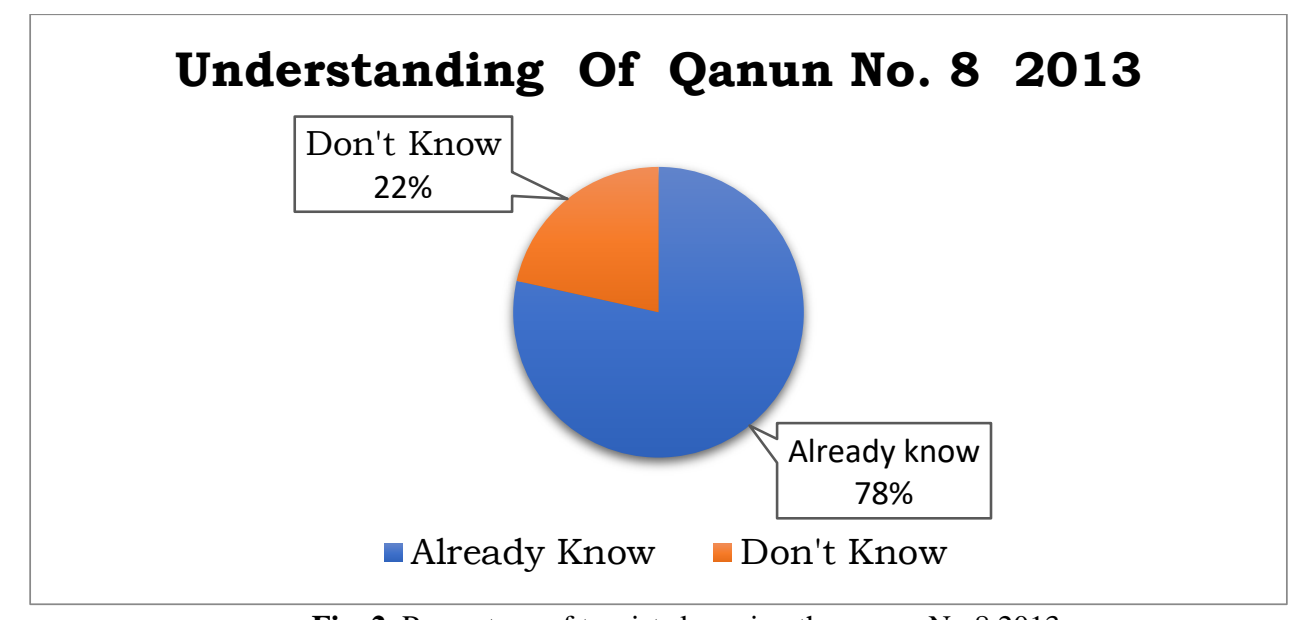

Fig. 2. Percentage of tourists knowing the qanun No 82013.

\subsection{Strategy for the Development of Pulau Weh Tourism Destinations, Kota Sabang}

External Environment Analysis

1. Opportunities

Are External Factors that have an advantage on the carrying capacity of the development of Pulau Weh tourist destinations, Sabang City, as for the following factors:

a. Local community support, namely cooperation carried out in the development of tourism objects.

b. Provide opportunities for local people to become entrepreneurs (selling tourist objects) so that it has a positive impact on increasing income.

c. The management carried out already has a legal basis, namely Aceh Qanun No. 8 of 2013.

d. Reducing unemployment by creating job opportunities for local people.

e. There is potential for foreign investors to come.

f. There are opportunities for collaboration with various stakeholders.

g. Preserving Aceh's culture through performances in the form of cultural festivals.

2. Threats

Are external factors that do not have an advantage on the carrying capacity of the development of Pulau Weh tourism destinations, Sabang City

a. Changes in the physical form of the environment due to new land clearing.

b. Chances of landslides due to land relocation.

c. The development of diverse tourist destinations makes competition quite high.

d. Decreased awareness of tourists and business actors in maintaining the cleanliness of the tourist environment.

e. There is a change in people's attitudes and behavior towards foreign culture.

f. The emergence of new tourism makes the government not focus on continuing to develop existing tourism.

g. There are facilities and infrastructure that escape the supervision of the local government and the tourism office. 
h. Lack of strict supervision and existing rules for prospective guests at several inns/hotels for non-Muhrim couples

\subsection{EFAS Matrix (External Factors Analysis Summary)}

Identifying internal factors where it is necessary to find out how these factors have a level of significance (significant) to strategic factors with a scale of 1 (not important), 2 (effective), 3 (very substantial). The weight is formulated by $\mathrm{J} x \mathrm{~J} t$, where $\mathrm{J} x$ : Total score of $\mathrm{X}$ factor and $\mathrm{J} t$ : Total score of external strategic factor. At the same time, the purpose of the rating is to provide a scale ranging from 4 to 1 based on the influence of these factors on tourism development in Pulau Weh, Sabang City. The results of the EFAS recapitulation above show that the city of Sabang has a higher opportunity than the threat with a chance threat value of $=2.187-0.540=1.647$. The EFAS SWOT chart can be seen in Figure 3 .

Based on Figure 3 in the diagram above, the Efas point at (1.647) is in Quadrant I, where this situation can be done by taking advantage of Strengths and Opportunities (SO) to increase the growth of tourist destinations on Weh Island, Sabang City. Optimizing existing opportunities and minimizing existing threats to be able to expand existing tourism and improve the community's economy, a trend that can invite foreign and domestic investors to participate in investing in the city of Sabang in increasing the development of existing tourism and minimizing the unemployment rate is in the town of Sabang and can improve the opinion of the region and the community.

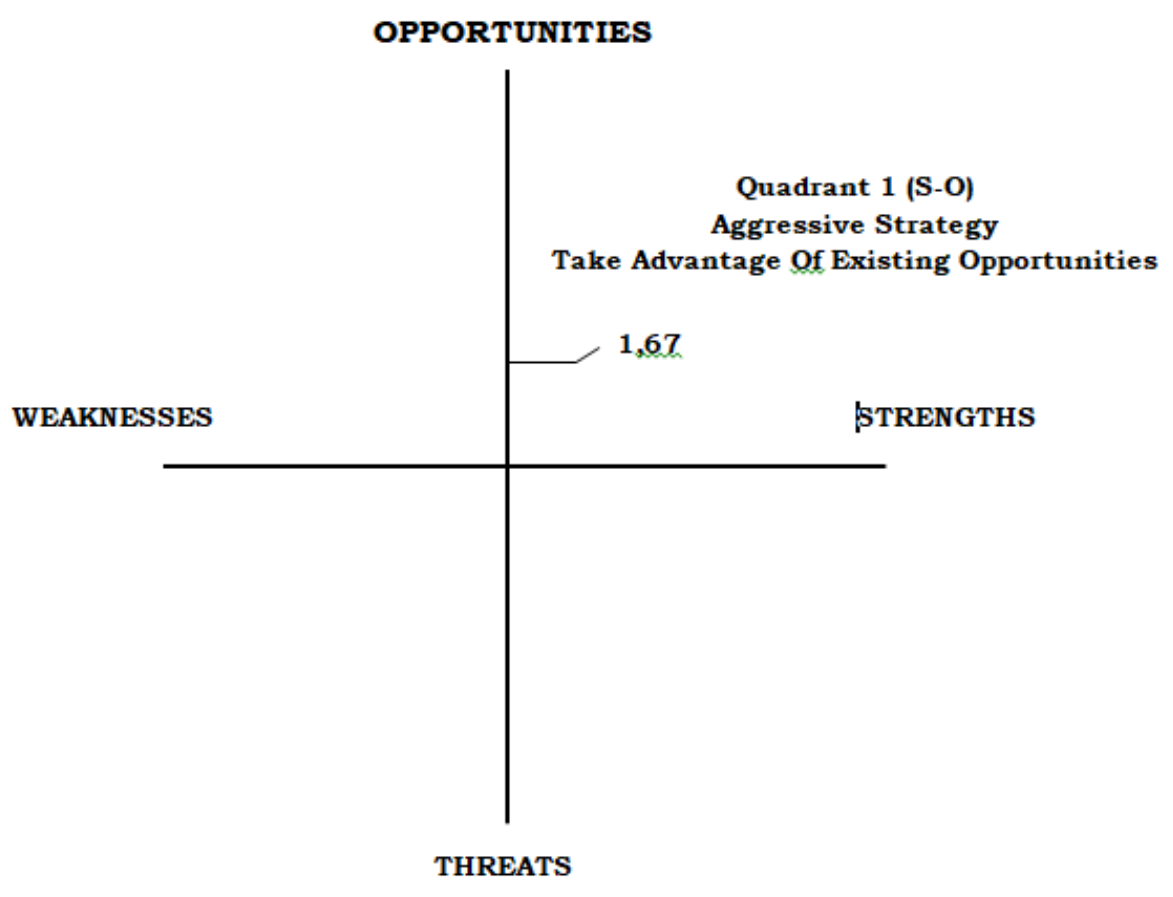

Fig. 3. EFAS SWOT Chart 


\section{Conclusion}

The city of Sabang is one of the cities in Aceh Province where the city of Sabang is a city that presents extraordinary natural beauty, of course, with this exceptional beauty, making the city of Sabang one of the tourist destinations for both local and foreign tourists. Tourism in Sabang refers to regional regulations or Aceh Qanun No. 8 of 2013, where the development and management of Islamic/halal-based tourism have been regulated in the Qanun. However, overall, Tourism in the city of Sabang is still not running halal tourism as the Qanun has handled where things This occurs due to the views of the community, business people, and tourists who argue that tourism in Aceh is halal because it is included in the area or city of the Veranda of Mecca. However, administratively Kota Sabang tourism still does not meet halal tourism. This can be seen in the graph of the level of understanding of Aceh's regional regulations or Aceh Qanun No. 8 of 2013 [16]. There is 78\% know about the Qanun, and the remaining $22 \%$ do not know.

Kota Sabang tourism is equipped with facilities and infrastructure to support the tourism sector based on the recapitulation of existing facilities and infrastructure in 25 tourist destinations in the city of Sabang; there are three tourist destination facilities in the wrong category, 20 in the medium type and the rest in the good class and on the infrastructure of tourist destinations in the city of Sabang, there are four tourist destinations in the wrong category, 5 in the medium type and the rest in the good class. In addition, the city of Sabang is also a city with a low crime rate, making the city of Sabang a friendly town for tourism, making tourists feel at home in the city of Sabang.

The tourism destination development strategy consists of external opportunities or opportunities (score 2.187), threats or threats (score 0.54). The alternative strategy to be carried out in the SO (Strengths - Opportunities) strategy in Quadrant I is to support an aggressive strategy. An alternative approach is the utilization of the potential of tourist attractions in an integrated manner to improve the community's economy, which provides opportunities for employment opportunities in the tourism sector in the city of Sabang. An environment with a natural ecosystem offers great opportunities in the tourism sector.

\section{References}

[1] Aditya IWP, Ardika IW, Pujaastawa IBD. Faktor Pendorong dan Implikasi Perkembangan Pariwisata Spiritual di Kawasan Pariwisata Ubud. Jurnal Master Pariwisata (JUMPA). 2019; 8(10) :109-109.

[2] Erianto E. Pengaruh Kualitas Fasilitas terhadap Kepuasan Pelanggan untuk Berkunjung kembali di Kabupaten Humbang Hasundutan. Jurnal Akademi Pariwisata Medan. 2020; 8(1): 77-90.

[3] Ginting N, Aritonang SR. Kajian Kenyamanan pada Fasilitas Pendukung Pariwisata di Desa Tomok. Prosiding Temu Ilmiah IPLBI 2019, Query date: 2021-06-25 14:24:54.

[4] Rahman A, Rezai R, Mohamed G, Shamsudin ZMN, Sharifuddin J. Malaysia as Global Halal Hub: OIC Food Manufacturers' Perspective. Journal of International Food \& Agribusiness Marketing. 2013; 25(1):154-166.

[5] Samori Z, Salleh NZ, Khalid MM. Current trends on Halal tourism: Cases on selected Asian countries. Tourism Management Perspectives. 2016; 19:131-136.

[6] Anugrah K. Potensi Pengembangan Wisata Halal Dalam Perspektif Dukungan Ketersediaan Restoran Halal Lokal (Non Waralaba) Di Kota Gorontalo. Jurnal Pariwisata Pesona. 2017; 2(2).

[7] Bernik M, Indika DR, Dewi RK. Standar Penerapan Wisata Halal Bagi Pelaku Industri Pariwisata di Kota Bandung. Jurnal Pemberdayaan Masyarakat Madani (JPMM). 2019; 3(1): 83-93. 
[8] Battour M, Ismail MN. Halal tourism: Concepts, practices challenges, and future. Tourism Management Perspectives. 2016; 19: 150-154.

[9] Rahmawati R, Oktora K, Ratnasari SL, Ramadania R, Darma DC. Is It True That Lombok Deserves To Be A Halal Tourist Destination In The World? A Perception Of Domestic Tourists. GeoJournal of Tourism and Geosites. 2021; 34(1): 94-101.

[10] Ajis AA. Strategi Kebijakan Menjaga Warisan Budaya Bandar Aceh Darussalam Di Kota Banda Aceh, Provinsi Aceh. Jurnal Konservasi Cagar Budaya. 2019; 13(2): 45-65.

[11] Dhuhri S. Aceh Serambi Mekkah (Studi tentang Peran Ibadah Haji dalam Pengembangan Peradaban Aceh). Jurnal Ilmiah Islam Futura. 2017; 16(2): 188-188.

[12] Azman Z. Strategi Humas Dinas Pariwisata Kota Banda Aceh Dalam Membangun Banda Aceh Sebagai Kota Pariwisata (Studi Pada Dinas Pariwisata Banda Aceh). Jurnal Peurawi. 2019; 2(2): 46-46.

[13] Budiman I., Kamal S, \& Tarlis A. Strategi Pemerintah Daerah Kota Langsa Povinsi Aceh dalam Mengembangkan Obyek Wisata Halal. Jurnal Samudra Ekonomi Dan Bisnis. 2019; 11(1):16-28.

[14] Maulida D. Tourism Destination Branding: Analisis Strategi Branding Wisata Halal "The Light Of Aceh (Studi Kasus pada Dinas Kebudayaan dan Pariwisata Aceh Tahun 2015-2016). Jurnal Ilmu Komunikasi. 2019; 5(1).

[15] Muis M. Perkembangan Peluang dan Tantangan Wisata Halal di Aceh. Jurnal Adabiya. 2020; 22(1): 41-41.

[16] Qanun Aceh Nomor 8 Tahun 2013 Tentang Kepariwisataan; 2013.

[17] Ghani YA. Pengembangan Sarana Prasarana Destinasi Pariwisata Berbasis Budaya di Jawa Barat. Jurnal Pariwisata. 2017; 4(1): 22-31. 